Revista Eletrônica Geografar, Curitiba, v. 2, Resumos do VI Seminário Interno de Pós-Graduação em

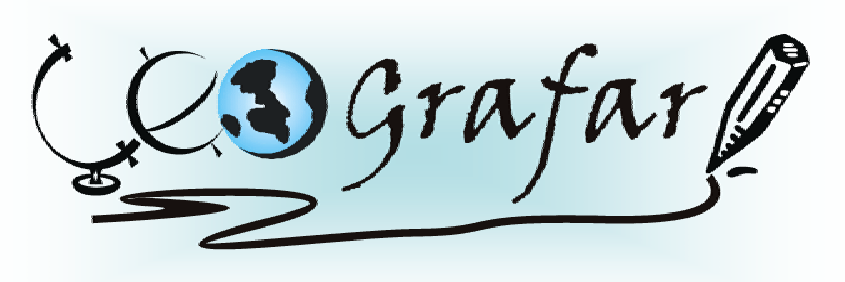

Revista Eletrônica do Programa de Pós-Graduação em Geografia - UFPR

\title{
A AGLOMERAÇÃO URBANA DA TRÍPLICE FRONTEIRA: FOZ DO IGUAÇU NO CONTEXTO DO PARANÁ.
}

\author{
FERNANDO RAPHAEL FERRO DE LIMA ${ }^{1}$
}

O presente artigo trata de dois assuntos e lança algumas hipóteses para a discussão a cerca da questão urbana e regional em nível internacional. O primeiro deles é a requalificação da aglomeração urbana de Foz do Iguaçu na tríplice fronteira, usando informações estatísticas para criar uma série histórica do crescimento populacional nos lados do Brasil, Paraguai e Argentina. Para isso, são trabalhados outros indicadores, de ordem econômica e social, caracterizando a aglomeração urbana, entre eles o de produtividade da população ocupada, mortalidade materna e infantil e IDH. Através da comparação com outros municípios percebe-se que a situação da cidade de Foz do Iguaçu é favorável em vários indicadores na comparação com outras cidades médias. O segundo ponto é fazer a discussão acerca do conceito de aglomeração urbana empregado em vários estudos, e sua aplicação no contexto do Estado do Paraná. Após a avaliação do conceito e a recontextualização, a aglomeração urbana da tríplice fronteira, da qual Foz do Iguaçu participa, desponta como uma das maiores da região sul do Brasil. Através dessas informações são lançadas duas hipóteses: a primeira é a de que o oeste paranaense pode ser compreendido como um estado região em formação, em conjunto com o leste paraguaio. O centro urbano desta região seria a aglomeração urbana da tríplice fronteira. A segunda diz respeito ao papel de Foz do Iguaçu na rede urbana de cidades, onde ela aparece numa posição pouco expressiva apesar da população de sua aglomeração ser superior a de centros melhor posicionados nestes estudos, como Cascavel. Dessa forma lança-se a idéia de que esse comportamento poderia ser explicado pela ausência de informações sobre a influência de Foz do Iguaçu na rede de cidade do Paraguai e do próprio papel das cidades paraguaias na rede brasileira.

Palavras-chave:

Aglomerações urbanas - Integração econômica internacional - Tríplice Fronteira.

1'Doutorando em Geografia - UFPR - email: Fernandoraphaelferro@yahoo.com.br 